Удк 94 (571.5)

ББК 63.32

\title{
БАНКОВСКАЯ СФЕРА ИРКУТСКА \\ В ПЕРИОД НАЦИОНАЛИЗАЦИИ (декабрь 1917 - июль 1918)
}

Рассматриваются обстоятельства национализации банковской сфреры г. Иркутска с приходом власти большевиков в декабре 1917 июле 1918 гг. Приводятся фракты об исключительном положении банка при Сиропитательном доме Е. Медведниковой и отделения Московского народного банка в г. Иркутске. Указываются причины, обусловившие особенность их положения.

Ключевые слова: Иркутск, кредитная сфрера, частные банки, банк при Сиропитательном доме Е. Медведниковой, Иркутское отделение Московского народного банка, банк Иркутского общества взаимного кредита, кооперация, советская власть, национализация. 
E. V. PLOTNIKOVA

\section{THE BANKING SECTOR OF IRKUTSK IN THE PERIOD NATIONALIZATIONS (December 1917 - July 1918)}

Discusses the circumstances of the nationalization of the banking sphere in Irkutsk with the coming to power of the Bolsheviks in December 1917 - July 1918. There are given the facts about the exceptional position of the Bank at the orphan's house of E. Medvednikova and the branch of the Moscow narodny bank in Irkutsk. The reasons behind the peculiarity of their position.

Keywords: Irkutsk, credit sphere, private banks, Bank at the orphan's house of E. Medvednikova, Irkutsk branch of the Moscow narodny bank, Bank of the Irkutsk mutual loan society, cooperation, soviet power, nationalization.

Национализация банковской сферы в России явилась одной из первоочередных задач большевиков после их силового захвата власти в октябре 1917 г. Национализации банков В. И. Ленин отводил место в числе мер, составляющих первый шаг на пути к освобождению народа от «каторжного», «безмерного» труда и полуголодной жизни, следующей за конфискацией помещичьих земель и введением рабочего контроля на предприятиях [11, с. 196]. 14 декабря 1917 г. вышли два декрета ВЦИК «О национализации частных акционерных банков и банкирских контор» и «О ревизии стальных ящиков в банках» [5; 6]. С этого момента банковское дело в России признавалось монополией государства, и все частные акционерные банки и банкирские конторы подлежали объединению с Государственным банком. Декреты явились юридическим обоснованием уже запущенного на тот момент в стране процесса национализации частной банковской ссреры. Фактически этот процесс начался утром 27 декабря 1917 г., когда в Петрограде отрядами красногвардейцев было захвачено 28 коммерческих банков и их отделений. Декрет о национализации банков был принят лишь вечером, в то время как захват банков стал фрактом свершившимся [1, с. 145].

В Иркутске служащие банковской сферы впервые ощутили вмешательство внешних сил в свою привычную работу 4 декабря 1917 г., когда в иркутские банки были введены вооруженные отряды большевиков. Спустя четыре дня в городе разразились бои, в результате которых после временного соглашения сторон, власть в округе, губернии и г. Иркутске перешла к Комитету советских организаций Восточной Сибири. При Комитете были образованы отраслевые отделы, которым должны были подчиняться все иркутские правительственные учреждения [2, с. 1]. На время декабрьских боев жизнь в городе замерла. Была приостановлена 
и работа кредитных учреждений, которые поспешили возобновить свою деятельность сразу же по их окончании. Однако после установления власти в регионе, большевики в скором времени повторили захват помещений банков, снова введя в них свои вооруженные силы и приставив их к банковским кладовым 18 января 1918 г. [8, с. 3]. Через четыре дня директора иркутских банков, приглашенные в отделение Волжско-Камского банка, были вынуждены сдать ключи от кладовых управляющему Иркутским отделением Государственного банка Гадзяцкому. Ключи поторопилось сдать и руководство Банка иркутского общества взаимного кредита, как выяснится впоследствии, поспешно. Таким образом, 22 января 1918 г. состоялась фактическая национализация практически всех частных банковских учреждений г. Иркутска. Исключение составили лишь два учреждения: Иркутское отделение Московского народного банка и банк при Сиропитательном доме Е. Медведниковой.

Причины, позволившие Московскому народному банку избежать национализации, хотя юридически он и относился к частным акционерным, состоят в масштабном протесте кооператоров, охватившим значительную часть страны, после захвата большевиками его центрального отделения в Москве в период с 12 по 15 декабря 1917 г. [9, с. 49]. Кооперативные круги Москвы и Петрограда отреагировали незамедлительным и сильным протестом. Такая же реакция последовала и от союзов кооперативов Ярославской, Новгородской, Костромской, Вологодской, Тверской, Владимирской и Тульской губерний, собравшимся на съезд 18 декабря 1918 г. Возмущенный возглас последовал и от Иркутского торгово-промышленного товарищества потребительских кооперативов (Ирсоюза). Кооператорами были направлены переполненные негодования телеграммы в адрес Совета народных комиссаров, Совета крестьянских депутатов, Центрального комитета партии социалистов-революционеров (эсеров), Учредительного собрания и Всероссийского Кооперативного Союза. В своих телеграммах кооператоры требовали восстановления деятельности Московского народного банка как главной опоры всей российской кооперации в неизменном виде [10, с. 30]. В фреврале 1918 г. I Всероссийский кооперативный съезд, проходивший в Москве, выразил недоверие власти советов, после чего советский наркомат продовольствия в заготовке и распределении продуктов принял решение положиться в своей деятельности на кооперацию [9, с. 49].

Банк при Сиропитательном доме Е. Медведниковой в процессе первой волны национализации, также не подчинился общим правилам и имел свой собственный путь. В январе 1918 г. в банк было направлено заявление заведующего финансовым отделом Комитета советских организаций Б. Славина с уведомлением о преобразовании Медведниковского банка в фрилиальное отделение Государственного и требованием передачи ему ключей от банковских кладовых под угрозой ареста 
в случае сопротивления [4, л. 5]. 18 января 1918 г. в помещение Медведниковского банка советскими властями был введен военный караул, приставленный к кладовым банка. 20 января 1918 г. на заседании Совета сиропитательного дома, управлявшего делами банка заместитель городского головы К.П. Турицын предложил передать ему ключи от кладовых, что и было сделано [9, л. 5]. После фракта передачи ключей попечители совета заявили о прекращении своих полномочий и ответственности в части заведывания операциями банка. Таким образом, к моменту собрания 22 января 1918 г., на которое советскими властями было приглашено руководство иркутских банков, Медведниковский банк уже передал ключи городскому общественному управлению, в ведении которого состоял с 1895 г. На собрании руководство банка заявило, что он не относится к категории частных акционерных, о которых шла речь в советском декрете, а принадлежит к городским общественным, и поэтому отказывается от передачи ключей управляющему иркутским отделением Государственного банка и передает их городскому управлению.

Впоследствии иркутские большевики получили телеграмму из Петрограда с указанием на то, что Иркутское отделение Московского народного банка, также как Банк Елизаветы Медведниковой и Банк общества взаимного кредита, национализации не подлежит [12, с. 3]. Иркутское общество взаимного кредита получило от заведующего финансовым отделом советских организаций Б.А. Славина уведомление о том, что советская власть находит возможным разрешить открытие банка общества при условии усиленного контроля со стороны Государственного банка. Дополнительному контролю при этом подлежали операции ссуд под товары и векселя. На товарные ссуды требовалось разрешение продовольственного отдела советских организаций, на ссуды под векселя - разрешение отдела труда [13, с. 4]. Правление общества взаимного кредита сочло указанные условия приемлемыми, и работу банка было решено в ближайшем будущем возобновить.

Банку Е. Медведниковой было разрешено продолжить свою работу при условии предоставления еженедельных отчетов в отделение Государственного банка и введения в банк комиссара, обладающего правом вето [4, л. 7]. С марта 1918 г. в банк стали поступать заявления от заемщиков. Все они были примерно одного содержания. Граждане, взявшие кредиты под покупку домов с целью последующей сдачи квартир в аренду, лишались своих доходов ввиду участившихся случаев реквизиции имуществ граждан советскими властями. Так как доходы от сдаваемых квартир служили финансовым обеспечением погашения долговых обязательств перед банком, данная категория заемщиков попадала в затруднительное положение. С одной стороны, заемщики лишались доходов, с которых выплачивался кредит, с другой, - имущества, которое можно было продать для того, чтобы погасить ссуду. Все заяви- 
тели просили о приостановлении платежей и начисления процентов по ссудам до возвращения их имуществ или выплаты по ним компенсаций [3, л. 3-5, 12, 16]. В ответ банк принял решение об отсрочке долгов заемщиков до 10 апреля 1918 г., продлив его впоследствии до 25 июля 1918 г. [3, л. 9, 34]. 2 мая 1918 г. была упразднена иркутская городская дума. Вследствие этого обстоятельства перед банком Е. Медведниковой с неотвратимой очевидностью вновь встал вопрос о национализации. Через два дня после роспуска думы руководству банка было направлено письмо из финансового отдела областного Восточно-Сибирского комитета советов рабочих, солдатских, крестьянских и казачьих депутатов. В письме сообщалось о роспуске городской думы и о переходе Медведниковского банка в ведение комиссара финансов иркутского совдепа, которому вменялось высшее руководство банком. Банк обязан был предоставлять комиссару все свои отчеты и инструктироваться с ним в своей деятельности [3, л . 10, 10 об.]. С этого момента банк Е. Медведниковой утратил свою самостоятельность и фактически был национализирован советской властью в процессе первой волны национализации, прокатившейся по Иркутску с декабря по июль 1918 г.

Что касается отделения Московского народного банка, то оно продолжало работать весь указанный период. Это напрямую было связано с политикой большевиков в отношении российской кооперации, в целом. В первые месяцы своего установления, боясь недовольства широких социальных масс, советская власть пыталась идти на сотрудничество с кооперацией. На последнюю власть возлагала надежды в налаживании системы учета и распределения продукции в масштабах всей страны. 10 апреля 1918 г. вышел декрет СНК «О потребительских кооперативных организациях», которым кооперация становилась под контроль государства и обязывалась выполнять государственные задания в части распределения продуктов, а также их закупки, переработки и производства по поручению государственных органов снабжения и BCHX. По мере укрепления своих позиций в стране советская власть усиливала и свое давление на кооперацию. Этот процесс привел к национализации Московского народного банка в соответствии с декретом от 2 декабря 1918 г. Декрет не имел принципиального значения для иркутского отделения Московского народного банка, которое продолжало свою работу вплоть до возвращения власти советов в Иркутск в январе 1920 г.

Таким образом, в процессе первой волны национализации банковской сферы, развернувшейся вслед за установлением советской власти в Иркутске в декабре 1917 г., были национализированы практически все местные банки. Процесс национализации, в большей или меньшей степени, затронул все кредитные учреждения Иркутска, за исключением Иркутского отделения Московского народного банка. Исключительность его положения обусловливалась значительной экономической и соци- 
ально-политической ролью кооперативного движения, представлявшего угрозу советской власти в случае перехода его в оппозицию. В этой связи большевики были вынуждены решать проблему огосударствления кооперации эволюционно, предпринимая очередные шаги параллельно с укреплением своих позиций на фронтах страны. Такая выверенная «антиконфликтная» политика позволила привлечь на свою сторону кооперативные народные массы и постепенно вовлечь их в процесс переустройства народного хозяйства страны на новых социалистических началах.

\section{Список использованной литературы и источников}

1. Бирюшкина Н. И. Особенности становления банковской политики советского государства (с октября 1917 г. по март 1921 г.) / Н. И. Бирюшкина, К. С. Ядрышников // Вестник Нижегородского университета им. Лобачевского. 2007. — № 4. - С. 143-148.

2. Власть труда. - 1917. - № 1.

3. Государственный архив Иркутской области (ГАИО). - Ф.156. - Оп. 1. Д. 286.

4. ГАИО. - Ф. 156. - Оп. 3. - Д. 21.

5. Декрет ВЦИК «О национализации частных акционерных банков и банкирских контор» от 14 декабря 1917 г. [Электронный ресурс] // Архивы России. - Режим доступа : http://www.rusarchives.ru/projects/statehood/08-25dekret-vcyk-1917.shtml.

6. Декрет ВЦИК «О ревизии стальных ящиков в банках» от 14 декабря 1917 г. [Электронный ресурс] // КонсультантПлюс. — Режим доступа : http://www.consultant. ru/cons/cgi/online.cgi?req=doc\&base=ESU\&n=4306\#05767616502910771

7. Илларионова Е. Становление кредитно-банковской системы в советский период (1917-1926 годы) / Е. Илларионова // Observer. - 2008. - № 12. С. 50-59.

8. Иркутские вести. - 1918. - № 1.

9. Кротов Н. И. Московский народный банк. 100 лет истории / Н. И. Кротов. М. : Международные отношения, 2011. - 679 с.

10. Кооперативное дело. - 1918. - № 1-3.

11. Ленин В. И. Как организовать соревнование? [Электронный ресурс] / В. И. Ленин // ПСС Ленина. - Т. 35. - Режим доступа : http://leninvi.com/t35/p196

12. Новая Сибирь. - 1918. - № 9.

13. Суровый край. - 1918. - № 1.

\section{Информация об авторе}

Плотникова Елена Владиславовна - аспирант, кафедра истории России, Исторический фракультет, Иркутский государственный университет, 664003, г. Иркутск, ул. К. Маркса, 1; e-mail: elena-angarsk@yandex.ru

\section{Author}

Elena V. Plotnikova - PhD Student, Department of History of Russia, History faculty, Irkutsk State University, 1 K. Marx St., 664003, Irkutsk, Russia; e-mail: elena-angarsk@yandex.ru 